\title{
Catastrophe in Stock Market in Bangladesh - A View of Investors and Financial Analysts of Chittagong Stock Exchange
}

\author{
Md. Hafij Ullah ${ }^{1}$, Mohammad Rokibul Kabir ${ }^{1} \&$ Monir Ahmmed ${ }^{1}$ \\ ${ }^{1}$ Department of Business Administration, International Islamic University Chittagong, Bangladesh \\ Correspondence: Md. Hafij Ullah, Department of Business Administration, International Islamic University \\ Chittagong, 240 Nawab Sirajuddowla Road, Chawk Bazar, Chittagong 4203, Bangladesh. Tel: 88-018-1817-7051. \\ E-mail: hafij_1980@yahoo.com
}

Received: April 4, 2012

Accepted: May 16, $2012 \quad$ Published: July 1, 2012

$10.5539 /$ ijef.v4n 7 p117

URL: http://dx.doi.org/10.5539/ijef.v4n7p117

\begin{abstract}
The indispensable part of an economy is Stock Market which acts as an intermediary for movement of funds between surplus units and deficit units. Well-functioning capital markets play an important role in mobilizing savings and investments for organizing the production of goods and services, creating employment opportunities, and enhancing economic development. But any sorts of disorder in the same may negatively affect the economy as a whole. The present study is an endeavor to justify the present conditions based on a chronological analysis of the history of stock market in Bangladesh identifying the reasons of the recent catastrophe, to measure the impact of the surge and fall on the investors simultaneously identifying their expectations from the regulatory bodies and to provide recommendations to overcome the present conditions.
\end{abstract}

Keywords: Catastrophe, Stock Market, regulatory bodies, syndicate, investors

\section{Introduction}

The indispensable part of an economy is Stock Market which acts as an intermediary for movement of funds between surplus units and deficit units. It is a place to raise capital by means of issuing share and hence transacting it on a regular basis among the participants. Thus, a share is just like a commodity sold in the stock market through stock exchange. By purchasing shares of a company an investor become the owner of that company up to the intrinsic value of his shareholding and also become entitled to the profit or loss of the company proportionate to his share.

In a market economy, the capital market plays a vital role in the efficient allocation of scarce resources. Well-functioning and developed capital markets augments the process of economic development, efficiency welfare through different ways such as encourage savings, draw more savers and users into the investment process, draw more institution into the intermediation process, help mobilization of non financial resources, attract external resources, discipline sick organization and investments organizing production of goods and services and creating employment opportunities (Chowdhury, T.A., 2005). There is a saying that the stock market is the pulse of the economy. In the developed western world, how the stock market is doing is not only a matter for prime-time news bulletin but also a matter of public interest on an hourly-basis. Keeping conspiracy theory aside, instability or extreme volatility of a capital market may suggest weaknesses in the market. Further, this is an indicator of looming economic uncertainty (Monem, R., 2011).

There is no doubt that a vibrant capital market is likely to support a robust economy but two major catastrophes in the capital market of Bangladesh within one and half decades do not indicate the existence of a vibrant market; rather these show a highly risky and unstable capital market. The recent surge in the capital market has shaken the whole country as millions of people became insolvent within a very short span of time. It was observed in 2010 that the DSE (Dhaka Stock Exchange) general index was the highest ever which made it Asia's top performer after China (Islam, 2011), while the reverse scenario was scaring investors in the 1st quarter of 2011 as the lowest down ever in the index was observed during that period.

The present study is an endeavor to justify the present condition of the stock market identifying the reasons of the catastrophe, to measure the impact of the surge and fall on the investors simultaneously identifying their expectations from the regulatory bodies and to provide recommendations to overcome the present conditions. 


\section{Objectives of the Study}

The main objective of the study is to analyze the reasons and impact of the recent catastrophe in the stock market in Bangladesh. To achieve the main objective, the study sets the following specific objectives:

i) To depict the present scenario of the stock market and the recent catastrophe of the stock market in Bangladesh through a chronological analysis of the history of stock market in Bangladesh.

ii) To find out the reasons of the recent catastrophe in the stock market in Bangladesh.

iii) To evaluate the impact of the recent catastrophe in the stock market in Bangladesh.

iv) To identify the expectations of the investors regarding the role of regulators and future prospects of the stock market in Bangladesh.

v) To provide some recommendations to overcome the present scenario of the stock market in Bangladesh.

\section{Methodology of the Study}

The present study is done based on the following methodology:

\subsection{Data Sources}

Both secondary and primary data were used for completion of the study. Secondary data were taken from different relevant studies, national and international dailies, websites of SEC, Bangladesh Bank, DSE, and CSE. Data regarding present market conditions, change in rules and regulations (SLR, CRR, etc.) and change in market index, etc. were collected from secondary sources.

Primary data were collected through a structured questionnaire survey. Relevant opinion market condition, investment, loan, loss on investment, roles of regulatory bodies, syndication, investigation report and expectation from regulators were collected from primary sources. Total 350 questionnaires were distributed out of which 255 (78.95\%) investors, $11(3.41 \%)$ financial analysts, $6(1.86 \%)$ executives of regulatory bodies and $51(15.80 \%)$ employees of brokerage houses totaling of $323(100 \%)$ respondents responded correctly. The respondents were chosen randomly from Chittagong Metropolitan area because of the convenient of the researchers. Because the working place of the researchers is in Chittagong.

\subsection{Demographic Characteristics of the Respondents}

Here an account of the demographic characteristics of the respondents is provided to understand the investors and overall capital market conditions of Bangladesh. The demographic characteristics are representing the overall demographic distribution of the population of Bangladesh. Based on age of the respondents were classified as: 136 (42.11\%) respondents fall in 20-29 years, 169 (52.32\%) respondents falls in 30-39 years and $18(5.57 \%)$ respondents fall in 40-49 years (Please See Table 1). As per profession, 15 (4.64\%) are businessmen, $265(82.04 \%)$ are service holders, $9(2.79 \%)$ housewives, $34(10.53 \%)$ are others (Please See Table 1). According to the educational background, $44(13.62 \%)$ respondents are undergraduate, $17(5.26 \%)$ respondents are graduate, $238(73.68 \%)$ respondents are post graduate, $24(7.43 \%)$ more or others (Please See Table 1). Based on the duration of involvement with the stock market, $68(21.05 \%)$ respondents are involved for less than 2 years, $85(26.32 \%)$ for 2-3 years, $51(15.80 \%)$ for $3-4$ years and $119(36.84 \%)$ for more than 4 years (Please See Table-2). Based on the reason or objective of involvement or investment in stock market the respondents can be classified as: $66(20.43 \%)$ to create self dependency, $36(11.15 \%)$ to upgrade social status, $119(36.84 \%)$ to earn higher return, $37(11.46 \%)$ easy to invest and $65(20.12 \%)$ other reasons (Please See Table-3). Based on the role of the respondents in the capital market, they can be divided into few groups as: 255 (78.95\%) Investors, 11 (3.41\%) Financial Analysts, 6 (1.86\%) Regulators and 51 (15.80\%) Stock Brokers (Please See Table 4). Finally according to the sources of capital the respondents can be divided into few groups as: 161 (52.96\%) investors invested only own money, $31(10.20 \%)$ investors invested taking fund from husband or father or relatives, 41 (13.49\%) investors invested taking bank loan, $24(7.90 \%)$ investors invested taking margin loan from broker, 47 (15.46\%) investors invested both own fund \& taking loan (Please See Table 8). 
Table 1. Age, Profession and Educational Status of Investors in capital market

\begin{tabular}{cccccc}
\hline Age & $20-29$ & $30-39$ & $40-49$ & Above 50 & Total \\
\hline Frequency & $136(42.11 \%)$ & $169(52.32 \%)$ & $18(5.57 \%)$ & - & $323(100 \%)$ \\
Profession & Business & Service & Housewife & Others & Total \\
Frequency & $15(4.64 \%)$ & $265(82.04 \%)$ & $9(2.79 \%)$ & $34(10.53 \%)$ & $323(100 \%)$ \\
Education & Undergraduate & Graduate & Post Graduate & More & Total \\
Frequency & $44(13.62 \%)$ & $17(5.26 \%)$ & $238(73.68 \%)$ & $24(7.43 \%)$ & $323(100 \%)$ \\
\hline
\end{tabular}

Source: Own Survey on Investors, Brokers and Regulators in Chittagong during March-May, 2011.

Table 2. Duration of involvement with stock market

\begin{tabular}{cccccc}
\hline Duration in Years & Less than 2 years & $2-3$ years & $3-4$ year & More than 4 years & Total \\
\hline Frequency & $68(21.05 \%)$ & $85(26.32 \%)$ & $51(15.80 \%)$ & $119(36.84 \%)$ & $323(100 \%)$ \\
\hline
\end{tabular}

Source: Own Survey on Investors, Brokers and Regulators in Chittagong during March-May, 2011.

Table 3. Why have you invested in stock market/ Reason of involvement?

\begin{tabular}{ccccccc}
\hline Opinion & $\begin{array}{c}\text { To create self } \\
\text { dependency }\end{array}$ & $\begin{array}{c}\text { To upgrade social } \\
\text { status }\end{array}$ & $\begin{array}{c}\text { To earn higher } \\
\text { return }\end{array}$ & $\begin{array}{c}\text { Easy to } \\
\text { invest }\end{array}$ & Others & Total \\
\hline Frequency & $66(20.43 \%)$ & $36(11.15 \%)$ & $119(36.84 \%)$ & $37(11.46 \%)$ & $65(20.12 \%)$ & $323(100 \%)$ \\
\hline
\end{tabular}

Source: Own Survey on Investors, Brokers and Regulators in Chittagong during March-May, 2011.

Table 4. Involvement with the stock market as

\begin{tabular}{cccccc}
\hline Involvement as & Investor & Financial Analyst & Regulator & Broker & Total \\
\hline Frequency & $255(78.95 \%)$ & $11(3.41 \%)$ & $6(1.86 \%)$ & $51(15.80 \%)$ & $323(100 \%)$ \\
\hline
\end{tabular}

Source: Own Survey on Investors, Brokers and Regulators in Chittagong during March-May, 2011.

After collecting data, simple statistical techniques like frequency distribution, percentage of frequency were used to analyze the collected data primary data and information.

\section{Limitations of the Study}

The present study is a self funded work and therefore it was not possible to collect opinion of all types of people relating to the stock market. It could be much more representative and comprehensive, if opinion could be collected from other parts of the country.

\section{Present Scenario of Stock Market and Recent Catastrophe}

\subsection{Capital Market at Present}

As on July 24, 2011 the number of active listed companies in the two stock exchanges are 270 (236 A-Category, 9 B-Category, $5 \mathrm{~N}$-Category and 20 Z-Category (Note-1)) and 212 respectively while there are 54 companies in the OTC Market. Among those the number of mutual funds traded is 32 in both the stock exchanges and that of bond traded in both DSE and CSE is 3. The market capitalization in the two stock exchanges is TK.3, 135,133,167,493 and Tk.2, 543,976,851,118 respectively. The number of $\mathrm{B} / \mathrm{O}$ Account holders at present is about 3.3 Million. Among them about 0.6 million are women. In the month of June, 2011 average daily turnover in DSE was 500 crore and in CSE it was 60 crore. Again the turnover has been showing an increasing trend as it stood at Tk.1958 crore in DSE and Tk.199 crore in CSE as on July 24, 2011.

\subsection{A Chronological Analysis of the History of Stock Market Catastrophe in Bangladesh}

The Stock Market of Bangladesh has got its origin from the then Pakistan through inheritance. Eight promoters have established the then East Pakistan Stock Market in between 1954-56. It was renamed as Dhaka Stock Exchange in 1964. The revolution of stock market has been initiated in 1976. A remarkable trade trend has been observed since 1986. The new General Index of Dhaka Stock Exchange has been established in 1993 by following the formula of International Finance Corporation (IFC) of World Bank. In the same year Security and Exchange Commission has been established as the regulatory body of Stock Market by the Parliament. 
From the year 1993 to 1994 market capital increased from Tk.178 crore to Tk.408 crore. Observing the high growth rate, the government introduced Lock-in period of one year for IPO to sponsors in the year 1995. In 1995, another stock exchange named Chittagong Stock Exchange was established. The year 1996 is marked as the worst year for the capital market of Bangladesh. In that year the capital market of Bangladesh has observed a big plunge in December after a bang having the market capital of Tk.2100 crore. Before the sag in December 1996, DSE General Index raised up to 3600 points through the "Pump and Dump Manipulation Scheme" of some dishonest stock brokers. After that the Index has declined by about 83.44\% in three years from 1996 to 1999.

Since no criminal responsible for that big plunge of 1996 has been punished, the sock market took long time to come to a stable position even though the Government had taken different initiatives. Such measures of the Government included the followings: Both the stock exchanges have started online trading since 1998. In 1999-2000, Government allowed black money to enter into the capital market (National Budget, 1999-2000). In 2000-2001, companies paying dividend $25 \%$ and above have been declared to get $10 \%$ tax rebate while tax deducted at source on bonus shares has been withdrawn by the Government. Permissions to the bank to open Merchant Bank wings and enhancement of minimum taxable income were other motivating effort during that period. But such efforts could not bring expected results as no mentionable progresses were found.

The slow and steady progress has been observed from 2002 to 2006. In 2007 the capital market of Bangladesh has got its momentum and it turned around with a rapid but stable growth which was a real booster for the investors. Market capital, index, average turnover and all other phenomena of stock market were showing a positive trend. Thus the period of 2007 to 2009 was the best period of Bangladesh Stock Market so far. In the 1st three quarters of 2010 investors have found a completely mysterious and unusual growth in capital market the ultimate consequences of which is the historical crush of 2010-2011. Other factors like economic situation, reduction of investment in other sectors, unemployment situation of the country and finally the encouragement of regulators for investment in stock market also played important role for unusual growth of stock market.

\subsection{Surge and Fall in Capital Market in 2010}

In 2010 the market reach at its peak and on 13th October, 2010 DSE regulators warned of a looming collapse of stock market as all flurry cooling measures failed to end a record breaking bull run. While the DSE general index doubled from a lower of 1318 in 2003-2004 to 3010 in 2008-2009 in five years, it hiked double in single fiscal year 2009-2010 to 6153. It had hit new highs consecutively five months reaching 8602 in 30th November, 2010 followed by a 290 points drop to 8290 in one month followed by a series of drop before the market crash on 10th January, 2011 to 6499. With a rebound on 12th January, 2011 to 7690 the index again fell on 19th January, 2011 following by a single day 587 points fall leading to a second crash. The capital market had to suffer another crumple in ten days while on 20th January, 2011 trading was halted at a loss of 587 points or $8.5 \%$ plunge within five minutes of start although it crossed the circuit breaker threshold of 225 points by a huge margin (Please See Table 5). The SEC has introduced the new circuit breaker a day earlier although it did not work at all (Akkas, 2011).

Table 5. DSE General Index and its change from November 2010 to May 2011

\begin{tabular}{cccccc}
\hline Date & $\begin{array}{c}\text { DSE General } \\
\text { Index }\end{array}$ & $\begin{array}{c}\text { Change in } \\
\text { General Index }\end{array}$ & Date & DSE General Index & $\begin{array}{c}\text { Change in } \\
\text { General Index }\end{array}$ \\
\hline $29 / 11 / 10$ & 8599.411 & -- & $20 / 02 / 11$ & 6389.625 & +810.120 \\
$05 / 12 / 10$ & 8918.514 & +319.103 & $28 / 02 / 11$ & 5203.085 & -1186.540 \\
$19 / 12 / 11$ & 7654.405 & -1264.110 & $10 / 03 / 11$ & 6639.181 & +1436.096 \\
$02 / 01 / 11$ & 8304.589 & +650.184 & $27 / 03 / 11$ & 6094.639 & -544.542 \\
$05 / 01 / 11$ & 7948.431 & -356.158 & $10 / 04 / 11$ & 6556.520 & +461.881 \\
$10 / 01 / 11$ & 6499.436 & -1449.000 & $26 / 04 / 11$ & 5806.309 & -750.211 \\
$12 / 01 / 11$ & 7690.690 & +1191.254 & $03 / 05 / 11$ & 5865.709 & +59.400 \\
$20 / 01 / 11$ & 6326.345 & -1364.350 & $08 / 05 / 11$ & 5611.471 & -254.238 \\
$30 / 01 / 11$ & 7572.610 & +1246.265 & $11 / 05 / 11$ & 5482.874 & -128.597 \\
$07 / 02 / 11$ & 6394.531 & -1178.080 & $12 / 05 / 11$ & 5612.519 & +129.645 \\
\hline
\end{tabular}

Source: Collected and rearranged based on data from www.bloomberg.com (Access date: 12-05-2011)

From that slump to till now the stock market in Bangladesh is continuing its lame run having some small crack and bounce. DSE General Index has shown a peculiar trend since 29th November. It declined from 6389.625 as on 29th November 2010 to 5612.519 as on 12th May 2011 with many sharp ups and downs as shown in the following graph: 


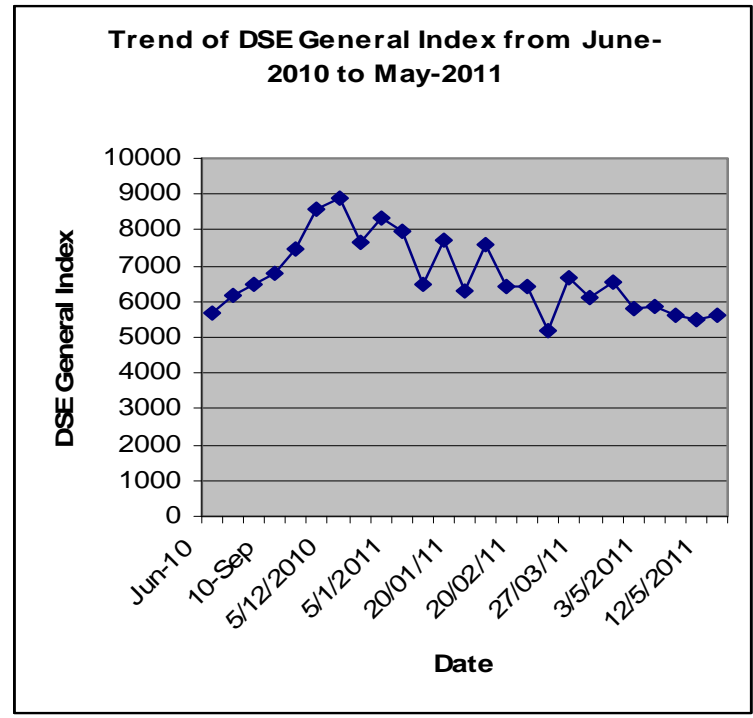

Figure 1. Showing the Movement of DSE General Index from June-'10 to May-'11

\section{Reasons of Recent Catastrophe in Stock Market}

\subsection{Role of Regulatory Bodies and Their Failure}

\subsubsection{The Government}

It is natural from micro point of view that an individual will plan his investment on the basis of fiscal policy of the government which is expressed through the annual budget in the Parliament. Similarly from the macro point of view, it is important to through light on future national economic policy by means of budget. So, it is obvious that everybody will look for a clear indication of the government plan regarding the activities of a fiscal year including its thinking about capital market. Thus, government plays an important role in the growth of capital market. But unfortunately, the government failed to do so in the recent years which brought the mighty blow on the stock market. In the fiscal year 2010-2011 the government has taken some risky decisions which helped to create a bubble in the market. Such decisions included the reduction of interest rate, imposing tax on Government Saving Certificates, providing facilities to enter black money in the stock market and so on. It is worth mentioning that both of the big plunges of 1996 and 2010 have been followed by the permission of whitening the black money through stock market. Moreover, the government has changed several regulations through SROs and other ways which brought the ailing fruits.

\subsubsection{Bangladesh Bank}

Bangladesh Bank as the regulatory body of financial market has the responsibility to materialize the plan of the government regarding financial market through controlling the activities of Banks and other financial institutions (Merchant Banks, Insurance Companies, Mutual Funds and Non-Banking Financial Institutions). Paradoxically Bangladesh Bank has failed to control the activities of financial market throughout the 2010-2011 fiscal year. During that period, most of the banks and their merchant banking wings invested in the stock market without following any rule. Even in some cases they invested money in capital market which they ought to invest in other industrial sectors. Bangladesh Bank did not take steps to abstain them from such activities up to the last month of 2010. But all on a sudden it realized the results of such unproductive investments and in December, 2010 it forced the banks to readjust its investments. Through a circular in December 2010, Bangladesh Bank increased Cash Reserve Requirements (CRR) from $5.5 \%$ to $6.00 \%$ and Statutory Liquidity Ratio (SLR) from $18.5 \%$ to $19.00 \%$ the obvious result of which was the liquidity crises. As a result a huge sales pressure helped the acceleration of the pace of the slump of capital market. "The small investors think that the Bangladesh Bank and the Securities and Exchange Commission are responsible for the stock market crash in an unholy alliance with the corporate culprits and the bankers believe the central bank is holding back and creating the liquidity pressure in the market. Some bankers feel the central bank is more interested in dabbling in 'esoteric banking' and has touch with the real world" (Ali, M.A, 2011).

\subsubsection{Security and Exchange Commission (SEC)}

Security and Exchange Commission (SEC) is the supreme regulatory body of capital market. So, it must have a formal plan of actions to regulate the activities of stock market. But ironically its failure in doing so is a matter of 
shame. Though it needs to impose rules considering the future growth, it became a kind of joker by frequently changing its own decisions because in 2010, the SEC issued 81 notifications, circulars and directives, of which 32 were related to the changing of margin loan ratio. The regulator revised the loan ratio from time to time although the changes in the ratio were made following the unusual rise and fall (Mufazzal, 2012). Even it has record of changing own decision within an hour of making it. It had to undergo a lot of criticism when its members made some very sensitive decision whimsically. The main reasons of such meaningless decisions are the lack of coordination among the members and involvement of many of them in share trading in others' name. Moreover, the manpower required to operate such an organization is not sufficient in SEC. It is unfortunate that SEC has no software of its own. Even it does not have any Chartered Accountant to ensure accurate audit report.

\subsubsection{DSE and CSE}

Dhaka Stock Exchange (DSE) and Chittagong Stock Exchange (CSE) play vital role in monitoring the activities of brokerage houses as well as the smooth functioning of stock market through giving permission of listing companies, delisting a certain company for violation of rules and other reasons, placing a company in a specific category (e.g. A, $\mathrm{B}, \mathrm{Z}, \mathrm{N}$ ) and queering unusual price hike of a particular script. It is a matter of sorrow both of the stock exchanges failed to ensure proper monitoring. Especially two activities of DSE played pivotal role behind the recent surge and plunge in the capital market. The first one is the circulation of news that within a very short period of time a huge number of Beneficiary Account (B/O) has been opened which was an indicator of the confidence of investors towards the capital market and can be compared with the provocation for investing money in the capital market. Thus it worked as a catalyst of price hike. Again DSE called for a press conference on 13th October, 2010 through which it urged people not to invest in the stock market as it became a risky sector according to them. It was a clear indication of upcoming crash. Thus it spread threat among the investors and they put a huge sell pressure even the institutional investors were also involved in force sell and trigger sell considering all the negative factors. Such a panic situation even provoked people to sell fundamentally strong shares.

\subsubsection{Credit Rating Agencies}

Investors get a clear picture of a company through its credit rating because such rating indicates the financial strength, management efficiency and growth potential of a company. At present there are four credit rating agencies in Bangladesh namely, (a) Credit Rating Agency of Bangladesh (CRAB), (b) Credit Rating Information and Services Limited (CRISL), (c) National Credit Rating Limited (NCRL) and (d) Emerging Credit Rating Limited (ECRL). But most of the listed companies are being rated by none of the above mentioned credit rating companies. As a result, investors are deprived of proper information about those companies which is one of the major obstacles of making informed investment decision.

In our research, which is conducted through a survey among 323 people from different areas including 255 investors, 11 Financial Analysts, 6 of different regulatory bodies and 51 brokers, it is found that $173(74+43+56)$ or $53.65 \%$ $(17.34 \%+23 \%+13.31 \%)$ of the investors surveyed believe that the role of the regulatory bodies are the main reason behind the recent catastrophe in Stock Market (Please See Table 6).

Table 6. Most serious cause of the recent catastrophe in the stock market

\begin{tabular}{cccccc}
\hline Opinion & $\begin{array}{c}\text { Lack of Govt. } \\
\text { awareness/ control } \\
\text { over the stock market }\end{array}$ & $\begin{array}{c}\text { Role of } \\
\text { SEC }\end{array}$ & $\begin{array}{c}\text { Role of Bangladesh } \\
\text { Bank in controlling the } \\
\text { investment of } \\
\text { commercial Banks }\end{array}$ & $\begin{array}{c}\text { Syndicate in } \\
\text { Stock Market }\end{array}$ & $\begin{array}{c}\text { Lack of proper } \\
\text { knowledge/ skill } \\
\text { of investors }\end{array}$ \\
\hline Freque-nc & $56(17.34 \%)$ & 74 & $43(13.31 \%)$ & $117(36.22 \%)$ & $34(10.53 \%)$ \\
$y$
\end{tabular}

Source: Own Survey on Investors, Brokers and Regulators in Chittagong during March-May, 2011. 


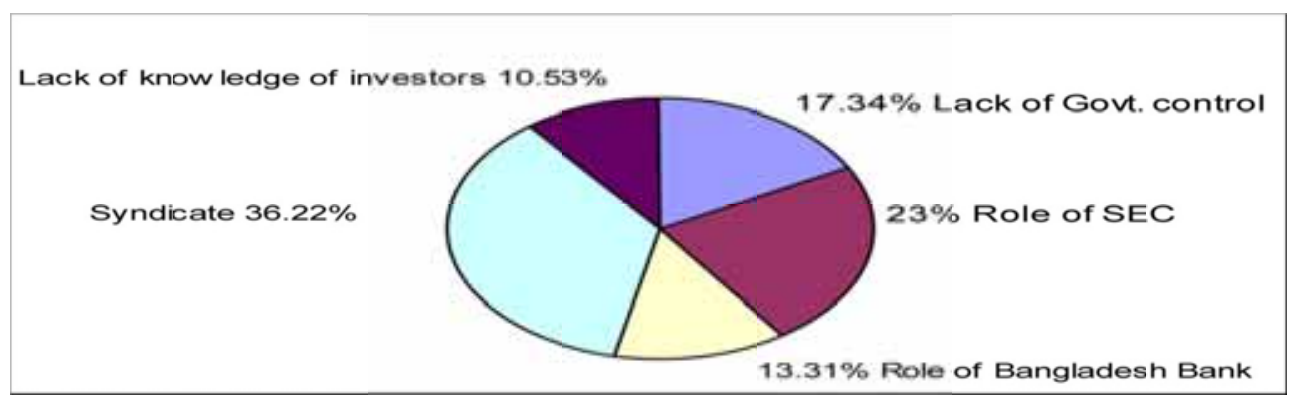

Figure 2. Most serious cause of the recent catastrophe in the stock market

Source: Own Survey on Investors, Brokers and Regulators in Chittagong during March-May, 2011.

Again, $151(46.75 \%)$ of the investors surveyed strongly agreed and $172(53.25 \%)$ agreed that the role of the regulators of stock market (SEC, DSE, CSE) is the main cause of the recent catastrophe. Most importantly, none of the respondents opined neutrally or negatively in this regard (Please See Table 7).

Table 7. Role of the Regulators (SEC, DSE \& CSE) is the cause of the recent catastrophe

\begin{tabular}{ccccccc}
\hline Opinion & Strongly Agree & Agree & Neutral & Disagree & Strongly Disagree & Total \\
\hline Frequency & $151(46.75 \%)$ & $172(53.25 \%)$ & - & - & - & $323(100 \%)$ \\
\hline
\end{tabular}

Source: Own Survey on Investors, Brokers and Regulators in Chittagong during March-May, 2011.

\subsection{Syndicate}

Like other market in Bangladesh, Syndicate is very much active in our capital market which is also found in the report of the Government Probe Committee report leaded by Khondkar Ibrahim Khaled. In their report they said that the stability of the stock market would not be achieved without political commitment at the highest level, only which is capable of eliminating the 'vicious cycle' ruling the market. The comment comes after the probe body has identified a myriad of corruptions committed by a section of powerful businessmen, politicians, stakeholders, key officials, and individual investors through syndication in the stock market.

The probe body identified a number of corrupt practices involving window-dressing of Balance Sheets, loop wholes in book building method, direct listing, private placement, share split, dividend declarations, preference shares and price manipulations in the secondary market and syndication among the above mentioned parties can be blamed for these manipulations.

In our study it is eminent that about 117 investors think syndication stock market is the main responsible factor for the recent catastrophe. The percentage of investors who thought so is $36.22 \%$ which is the highest weight among probable reasons as identified by the surveyed respondents (Please See Table 6).

\subsection{Education and Skills of Investors}

Though the number of B/O Account Holders is huge (About 33 lakh) in our stock market, but their education and skills in investment in stock market is not that good. In our study we found some investors who do not know even the $\mathrm{ABC}$ of stock of market. While talking with such investors we learned that they invest in the market either by taking others' advices or on the basis of rumor. Though unfortunate, it also came out that often they buy and sell shares seeing other big investors in the broker houses. When big parties buy shares, they also do so with the expectation of increase in price and vice-versa. From the study it is evident that $10.54 \%$ of the total respondents thought that lack of knowledge of the mass investors in the stock market about the appropriate way of analysis and investment decision is the main reason of the recent slump (Please See Table 6).

\subsection{Brokerage Houses}

Broker houses play important role in capital market operation as share trading are being facilitate through their participations. They sometimes violate different rules of DSE and CSE, for which the trading of six brokerage houses (namely, Securities arms of Dhaka Bank, NCC Bank, AIBL, PFI Securities, Alliance Securities \& Management, and IIDFC Securities) were banned for 30 days for triggering collapse on 20th January, 2011 and few 
top officials of those brokerage houses were given punishment. In our survey, about respondents $138(42.72 \%)$ thought that they are also responsible for the recent crash (Please See Table 6).

\subsection{Trading through Omnibus Account}

An omnibus account is a stock holding account that involves more than 10,000 investors, although actual shareholders or individual investors don't have the accounts in their own names. In the probe report regarding the recent catastrophe, Khondkar Ibrahim Khaled has stated that most big traders made transactions through the omnibus accounts of the ICB during the sessions of gain or loss. The committee held 30 big players responsible including the ICB for the recent plunge and all of these big players traded through omnibus accounts.

\section{Impact of the Recent Catastrophe}

From the study it is found that the sources of capital of the investors are different. Out of 304 investors surveyed 161 $(52.96 \%)$ investors invested only own money, $31(10.20 \%)$ investors invested taking fund from husband or father or relatives, $41(13.49 \%)$ investors invested taking bank loan, 24 (7.90\%) investors invested taking margin loan from broker, 47 (15.46\%) investors invested both own fund \& taking loan (Please See Table 8).

Table 8. Sources of capital of the investors in stock market

\begin{tabular}{cccccc}
\hline $\begin{array}{c}\text { Sources of } \\
\text { Capital }\end{array}$ & Own money & $\begin{array}{c}\text { Husband or } \\
\text { father }\end{array}$ & Bank loan & $\begin{array}{c}\text { Margin Loan } \\
\text { from broker }\end{array}$ & $\begin{array}{c}\text { Combination of } \\
\text { own \& loan }\end{array}$ \\
\hline Frequency & $161(52.96 \%)$ & $31(10.20 \%)$ & $41(13.49 \%)$ & $24(7.90 \%)$ & $47(15.46 \%)$ \\
\hline
\end{tabular}

Source: Own Survey on Investors, Brokers and Regulators in Chittagong during March-May, 2011.

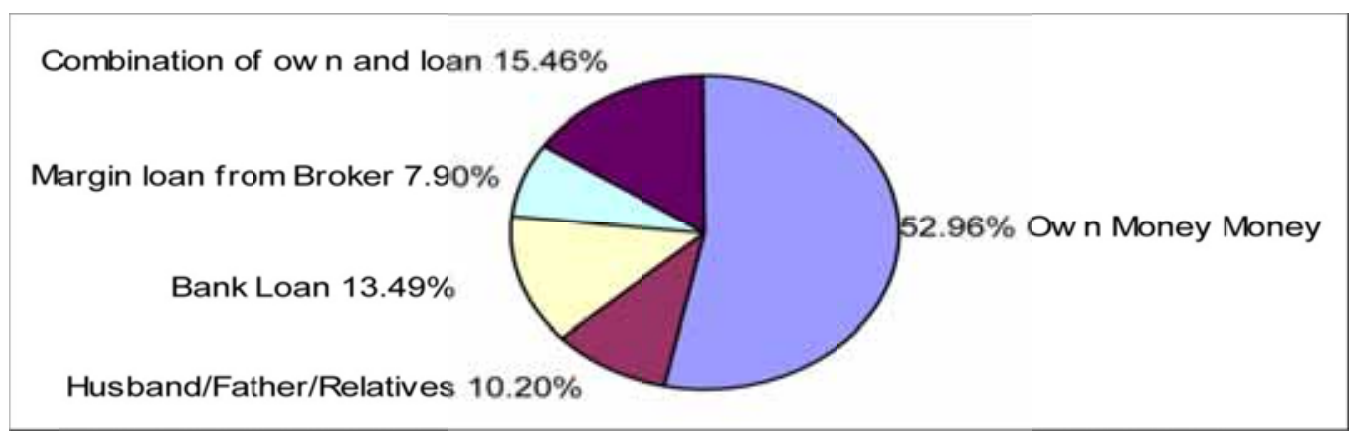

Figure 3. Sources of capital of the investors

Source: Own Survey on Investors, Brokers and Regulators in Chittagong during March-May, 2011.

\subsection{Loss of Own Capital}

The investment of $151(49.67 \%)$ investors surveyed was in the range of Tk. 1 lac to Tk.5 lac, $82(26.97 \%)$ investors surveyed was in the range of Tk. 5 lac to Tk.10 lac and only $12(3.95 \%)$ investors had investment of Tk.15 lac and above.

While 82 investors (26.97\%) were in the investment range of Tk.5 lac to 10 lac and $31(10.20 \%)$ in the investment range of 10 to 15 lac before the catastrophe, it came down to $62(20.39 \%)$ and $19(6.25 \%)$ respectively showing a decline of $24 \%$ and $38 \%$ respectively after the slump. Again, the number of persons having investment above 15 lac was 12 which is 8 now causing a decline of $50 \%$. Among the surveyed investors 183 have suffered a loss ranging Tk.1 lac to Tk. 5 lac (Please See Table 9).

Table 9. Comparison of original investment and investment after catastrophe

\begin{tabular}{ccccccc}
\hline $\begin{array}{c}\text { Class of } \\
\text { Investment }\end{array}$ & Below 1 lakh & $1-5$ lakh & 5 -10 lakh & $10-15$ lakh & Above 15 lac & Total \\
\hline Before Slump & $28(9.21 \%)$ & $151(49.67 \%)$ & $82(26.97 \%)$ & $31(10.20 \%)$ & $12(3.95 \%)$ & $304(100 \%)$ \\
After Slump & $46(15.13 \%)$ & $169(55.59 \%)$ & $62(20.39 \%)$ & $19(6.25 \%)$ & $8(2.63 \%)$ & $304(100 \%)$ \\
Change & $5.92 \%$ & $5.92 \%$ & $-6.58 \%$ & $-3.95 \%$ & $-1.32 \%$ & - \\
\hline
\end{tabular}

Source: Own Survey on Investors, Brokers and Regulators in Chittagong during March-May, 2011. 


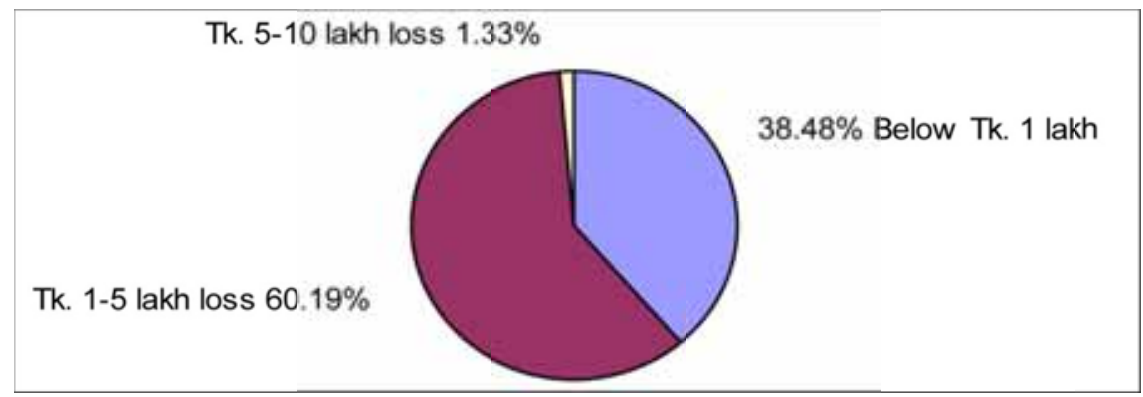

Figure 4. Own Capital loss due to recent catastrophe

Source: Own Survey on Investors, Brokers and Regulators in Chittagong during March-May, 2011.

More specifically, it can be observed from the above table that 117 (38.48\%) investors under survey lost below Tk. 1 lac, $183(60.19 \%)$ investors under survey lost Tk. 1 lac to Tk. 5 lac and 4 (1.33\%) investors under survey lost Tk. 5 lac to Tk. 10 lac (Please See Table 10).

Table 10. Own capital loss for the recent catastrophe in the stock market

\begin{tabular}{ccccccc}
\hline Own capital loss & Below 1 lakh & 1-5 lakh & $5-10$ lakh & $10-15$ lakh & Above 15 lakh & Total \\
\hline Frequency & $117(38.48 \%)$ & $183(60.19 \%)$ & $4(1.33 \%)$ & - & - & $304(100 \%)$ \\
\hline
\end{tabular}

Source: Own Survey on Investors, Brokers and Regulators in Chittagong during March-May, 2011.

\subsection{Loss of Borrowed Capital}

The investors also invested taking loan from banks and brokerage houses. Among the investors under survey, 43 (14.14\%) investors have took loan of below Tk. 1 lac, 57 (18.75\%) investors took loan in the range of Tk.1 lac to Tk. 5 lac, $23(7.57 \%)$ investors took loan in the range of Tk.5 lac to Tk. 10 lac, $13(4.28 \%)$ investors took loan in the range of Tk.10 lac to Tk. 15 lac, while only 7 investors (2.30\%) took loan above Tk. 15 lac (Please See Table 11).

Table 11. Amount of investment taking loan from different sources

\begin{tabular}{cccccccc}
\hline Class of loan & No loan & Below 1 lakh & 1-5 lakh & 5-10 lakh & $10-15$ lakh & Above 15 lakh & Total \\
\hline Frequency & $161(52.96 \%)$ & $43(14.14 \%)$ & $57(18.75 \%)$ & $23(7.57 \%)$ & $13(4.28 \%)$ & $7(2.30 \%)$ & $304(100 \%)$ \\
\hline
\end{tabular}

Source: Own Survey on Investors, Brokers and Regulators in Chittagong during March-May, 2011.

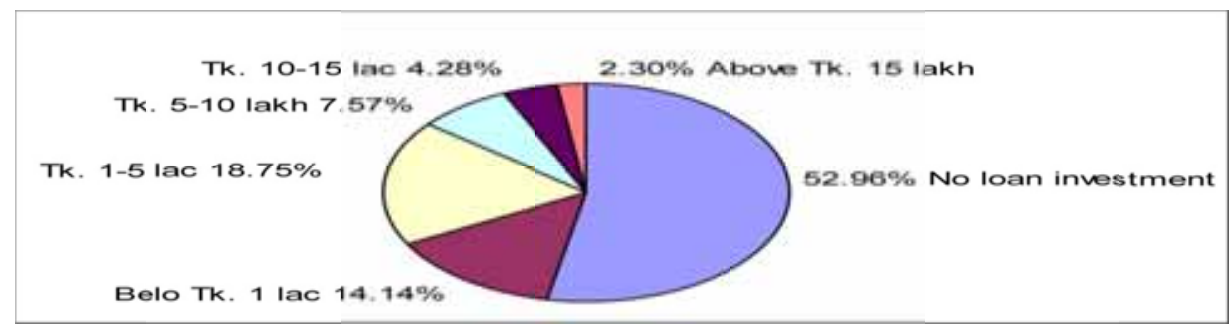

Figure 5. Loan/Borrowed capital investment in capital market

Source: Own Survey on Investors, Brokers and Regulators in Chittagong during March-May, 2011.

It is revealed from the study that the impact of the catastrophe is severe, especially on those who have taken loan. Out of 143 investors who have invested taking loan from different sources, 105 of them lost below Tk. 1 lac of their loan, 33 of them lost Tk. 1 lac to Tk. 5 lac of their loan, 5 of them lost Tk. 5 lac to Tk. 10 lac of their loan which are now to be paid from their personal assets (Please See Table 12). 
Table 12. Borrowed capital loss for the recent catastrophe in the stock market

\begin{tabular}{cccccccc}
\hline Borrowed capital loss & No Loan lost & Below 1 lakh & 1-5 lakh & $5-10$ lakh & 10-15 lakh & Above 15 lakh & Total \\
\hline Frequency & $161(52.96 \%)$ & $105(34.54 \%)$ & $33(10.86 \%)$ & $5(1.64 \%)$ & - & - & $304(100 \%)$ \\
\hline
\end{tabular}

Source: Own Survey on Investors, Brokers and Regulators in Chittagong during March-May, 2011.

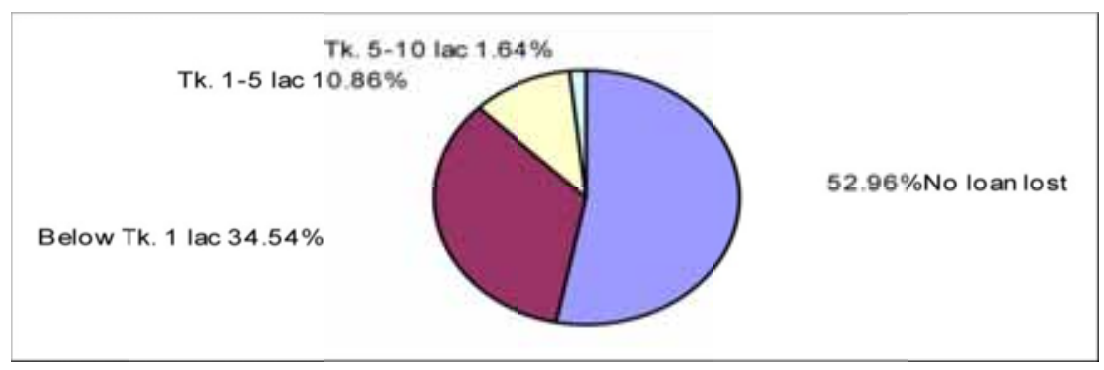

Figure 6. Borrowed capital loss due to recent catastrophe

Source: Own Survey on Investors, Brokers and Regulators in Chittagong during March-May, 2011.

\subsection{Interest Expense during the Period of Catastrophe}

The investors who have taken loan suffered not only for the loss of loan but also for interest payment on their loan which made the condition even worse. The study shows that $192(63.16 \%)$ investors have no interest expense because they have no loan or they invested taking loan from husband or father or relatives. $23(7.57 \%)$ of the investors require paying interest expense of Tk. 40,000 or above (Please See Table 13).

Table 13. Interest expense on the borrowings during this situation in the stock market

\begin{tabular}{cccccccc}
\hline $\begin{array}{c}\text { Interest } \\
\text { Expense }\end{array}$ & $\begin{array}{c}\text { No interest } \\
\text { Expense }\end{array}$ & $\begin{array}{c}\text { Below } \\
10,000\end{array}$ & $10,000-20,000$ & $20,000-40,000$ & $40,000-60,000$ & $\begin{array}{c}\text { More than } \\
60,000\end{array}$ & Total \\
\hline Frequency & $192(63.16 \%)$ & $\begin{array}{c}51 \\
(16.78 \%)\end{array}$ & $27(8.88 \%)$ & $11(3.62 \%)$ & $10(3.29 \%)$ & $13(4.28 \%)$ & $304(100 \%)$ \\
& & & & & & \\
\hline
\end{tabular}

Source: Own Survey on Investors, Brokers and Regulators in Chittagong during March-May, 2011.

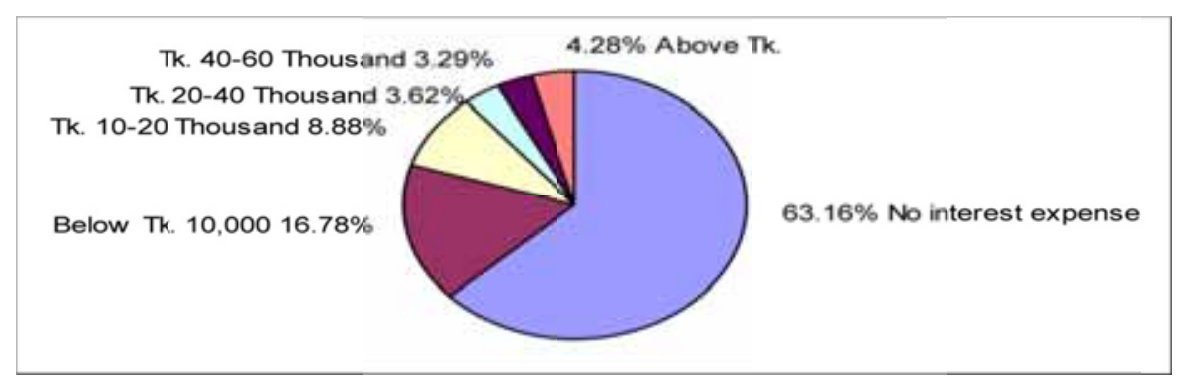

Figure 7. Interest Expense of the investors due to recent catastrophe

Source: Own Survey on Investors, Brokers and Regulators in Chittagong during March-May, 2011.

\subsection{Loss of Income Earned before Catastrophe}

It is also found that 128 (42.11\%) investors out of 304 have lost their earned money of Tk.1 lac to Tk. 2 lac, and 97 (31.91\%) have lost their earned money of more than Tk. 2 lac, which they earned before the recent catastrophe. The least number of investors fall in the range of less than Tk. 50,000, which indicate a heavy loss of investors for the recent catastrophe (Please See Table 14). 
Table 14. Loss of income for the recent catastrophe in the stock market

\begin{tabular}{cccccc}
\hline Loss of income & Less than 50,000 & $50,000-1$ lakh & $1-2$ lakh & More than 2 lakh & Total \\
\hline Frequency & $28(9.21 \%)$ & $51(16.78 \%)$ & $128(42.11 \%)$ & $97(31.91 \%)$ & $304(100 \%)$ \\
\hline
\end{tabular}

Source: Own Survey on Investors, Brokers and Regulators in Chittagong during March-May, 2011.

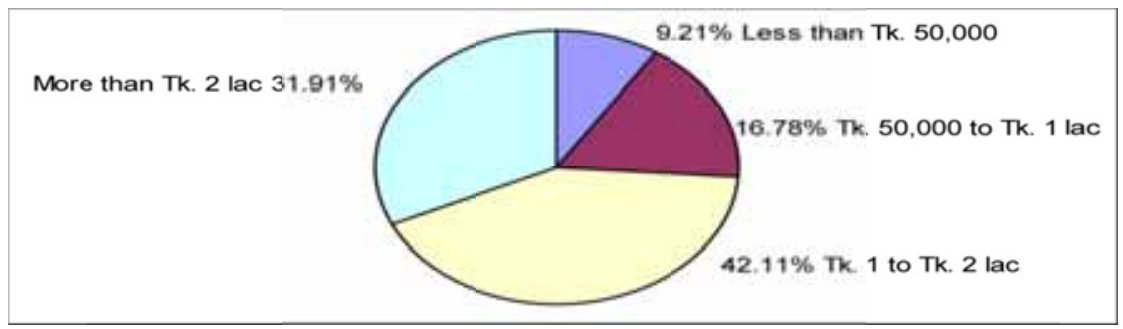

Figure 8. Loss of income due to recent catastrophe

Source: Own Survey on Investors, Brokers and Regulators in Chittagong during March-May, 2011.

Investors in the stock market not only lost their past earnings but also losing the current income. Many unemployed and retired persons also invested their last resorts in the capital market to earn something for living in a better way; but they are also suffering much due to this catastrophe in the stock market.

\section{Confidence on Investigate Report and Expectations from Regulators or Government for Changing the Present Scenario}

The highest number of the respondents have confidence on the report given by the Probe Committee led by Khondkar Ibrahim Khaled which is reflected in the result of the survey where $209(64.71 \%)$ of them believe that the report is either most accurate or accurate while only 28 (8.67\%) think it as inaccurate (Please See Table 15). It is revealed from the study that respondents, especially the investors want exemplary punishment of the criminal who were directly or indirectly involved with the recent catastrophe.

Table 15. Opinion regarding investigation report (By Mr. Ibrahim Khaled)

\begin{tabular}{lcccccc}
\hline Opinion & Most Accurate & Accurate & Inaccurate & Most Inaccurate & No Comment & Total \\
\hline Frequency & $36(11.15 \%)$ & $173(53.56 \%)$ & $28(8.67 \%)$ & - & $86(26.63 \%)$ & $323(100 \%)$ \\
\hline
\end{tabular}

Source: Own Survey on Investors, Brokers and Regulators in Chittagong during March-May, 2011.

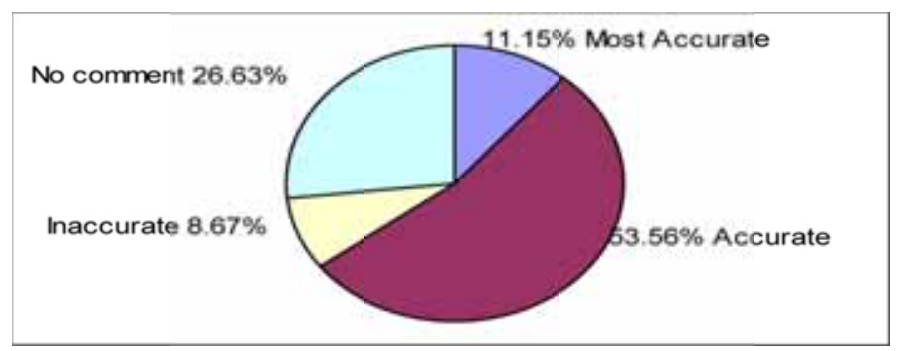

Figure 9. Opinion regarding investigation report (By Mr. Ibrahim Khaled)

Source: Own Survey on Investors, Brokers and Regulators in Chittagong during March-May, 2011.

From the study it is also found that investors think bounce back of capital market is possible and they intensely observed the appointment of the new members and chairman of Security and Exchange Commission (SEC). It is important to mention that most of the respondents are hopeful about the newly appointed body as $169(52.32 \%)$ respondents are either very optimistic or optimistic of getting the scenario change but they should be let free to work independently (Please See Table 16). 
Table 16. Expectation that present scenario will change due to re-structuring of SEC

\begin{tabular}{lccccc}
\hline Opinion & Very Optimistic & Optimistic & Pessimistic & Very Pessimistic & Total \\
\hline Frequency & $31(9.60 \%)$ & $138(42.72 \%)$ & $117(36.22 \%)$ & $37(11.46 \%)$ & $323(100 \%)$ \\
\hline
\end{tabular}

Source: Own Survey on Investors, Brokers and Regulators in Chittagong during March-May, 2011.

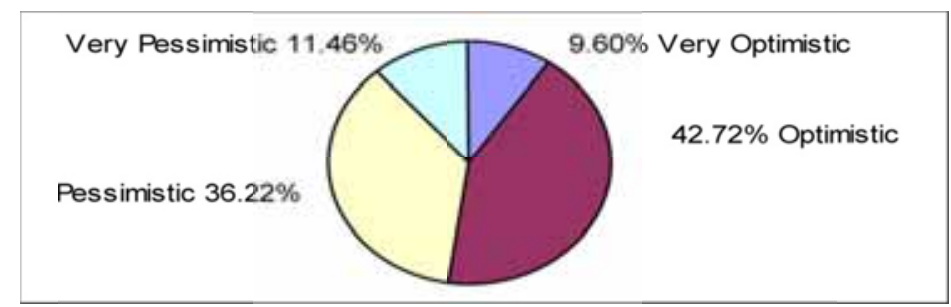

Figure 10. Expectation that present scenario will change due to re-structuring of SEC

Source: Own Survey on Investors, Brokers and Regulators in Chittagong during March-May, 2011.

As per the survey, the highest number of the respondents $124(38.39 \%)$ surveyed believe that the elimination of syndication and $34.67 \%$ of the investors expect the appointment of skilled, honest and efficient personnel in the regulatory bodies as the key to get the market changed. Moreover, action against the culprits behind the slump $(17.65 \%)$ and creation of awareness among the investors by arranging more training and skill enhancement programs $(21.05 \%)$ along with strong government control over the stock market (16.41\%) were also emphasized by the respondents (Please See Table 17).

Table 17. Expectations from regulators /Govt. for developing stock market in future

\begin{tabular}{cccccc}
\hline Opini-on & $\begin{array}{c}\text { More control of } \\
\text { Govern-ment over } \\
\text { stock market }\end{array}$ & $\begin{array}{c}\text { Organize more } \\
\text { training, seminar } \\
\text { and awareness } \\
\text { programs }\end{array}$ & $\begin{array}{c}\text { Appoint more } \\
\text { honest and skilled } \\
\text { person in the } \\
\text { regulatory bodies }\end{array}$ & $\begin{array}{c}\text { Taking immediate } \\
\text { action against the } \\
\text { liable person for the } \\
\text { catastrophe }\end{array}$ & $\begin{array}{c}\text { Elimination of } \\
\text { Syndicate from } \\
\text { the stock market }\end{array}$ \\
\hline Frequ-ency & $53(16.41 \%)$ & $68(21.05 \%)$ & $112(34.67 \%)$ & $51(17.65 \%)$ & $124(38.39 \%)$ \\
\hline
\end{tabular}

Source: Own Survey on Investors, Brokers and Regulators in Chittagong during March-May, 2011.

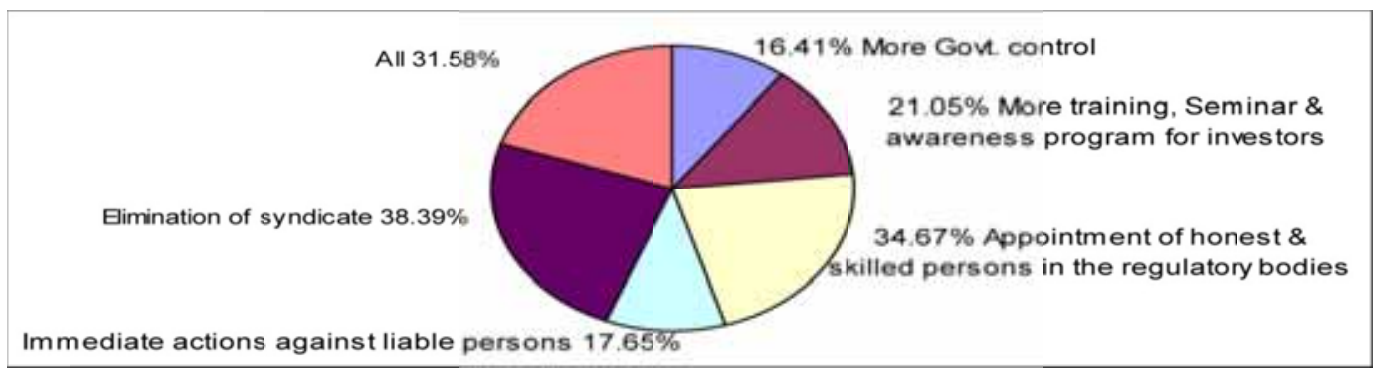

Figure 11. Investor's Expectations from Regulators/Govt.

Source: Own Survey on Investors, Brokers and Regulators in Chittagong during March-May, 2011.

\section{Recommendations of the Study}

It is crystal clear that for the sustainable development of stock market all the parties concerned must work in a harmony as failure of any of them may lead the market to a further long decline towards a deep dark tunnel. So, we would like to suggest a few recommendations for different stakeholders of capital market.

\subsection{Recommendations for the Government}

There is no doubt that the failure of the government in making various decisions regarding capital market played role behind the recent crash which was also admitted by the Planning and Finance Minister in his different speech. Thus, the govt. should ensure the followings: 
i) The responsible persons of the Government should refrain from delivering irrelevant, irresponsible and sensitive speeches which many of them did before.

ii) Government should delegate all power to the SEC to take legal actions against the criminals. Even if necessary, new Act may be passed in the Parliament in this regard.

iii) Flow of black money in the capital market must be restricted as it can never bring any good results in the long run other than creating bubble in the stock market the blast of which nothing but a disaster.

\subsection{Recommendations for Securities and Exchange Commission (SEC)}

SEC as the guardian of capital market should play significant role in its forward march. It must ensure the followings:

i) SEC must ensure that neither of its members nor any of its officials is involved either direct or indirectly with the transactions in the stock market.

ii) The monitoring and surveillance should be strengthen so that none can get chance to gamble.

iii) SEC must have its own certified Chartered Accountants to ensure the accuracy of the Financial Statements of the listed companies and they should give punishment if the books of accounts are not accurately audited.

iv) SEC must rethink about the rule of disclosure of quarterly financial reports by the companies because many of the companies misused it as a vehicle of misguiding the investors. In fact, it became a common practice of most of the listed companies to show high quarterly EPS in its un-audited quarterly report to bring down P/E ratio. In some cases, it is seen that a few companies' annual audited EPS for the year ended 2010 was lower than its accumulated EPS of three quarters.

\subsection{Recommendations for DSE and CSE}

Both Dhaka and Chittagong Exchanges have important role to play as the monitoring authority of the Broker Houses. So, they need to play vital role by ensuring the followings:

i) They must ensure proper monitoring of the brokerage houses for which more skilled manpower should be appointed in the Monitoring and Surveillance Team.

ii) Any sort of irregularities in case of trading should be identified promptly and immediate action should be taken.

iii) To aware investors having no or insufficient skills about the investment in stock market should be trained through different training programs, seminars and motivating fair.

iv) They should not make any public comment about the future of stock market which may create bubble and crash as we found in case of recent catastrophe.

\subsection{Recommendations for Bangladesh Bank}

Though Bangladesh Bank is the regulatory body of Money Market; but its decisions are also reflected in the capital market as the money market and capital market are interrelated. In this regard it has the following roles to play:

i) It must ensure that the Banks and Other financial institutions' exposures do not exceed the limit from the very beginning. But in the recent slump it failed to do so as it could not monitor the involvement in the early periods while it put pressure on the banks to readjust their capital market exposures at the eleventh hour which accelerate a huge sale pressure from their side.

ii) It must ensure the proper functioning of the Merchant Banks through arranging money from the parent company to mitigate liquidity crisis.

iii) It should keenly monitor the loan of the commercial banks to industrial sector and take regular feedback so that no industrial loan may flow to the capital market. It is found that in case of recent catastrophe, it failed to do so as about 72 crore taka taken for industrial loan has directly been invested in capital market according to the report of newspapers published in most of the dailies as on 5th December, 2010. Moreover, Bangladesh Bank has identified a Ready made Garments Exporter to take loan of Taka 36 crore and 74 lac for his business purpose and to invest in the capital market while a Berth Operating Organization of Chittagong port did the same amounting to Tk. 5 crore and 1 lac. According to a report published in the Daily Prothom-Alo on 5th November, a listed company has taken loan from a Government owned bank and invested in the stock market. There are many other such examples which urge for proper monitoring of Bangladesh Bank on time.

\subsection{Recommendations for Institutional Buyers}

Institutional Buyers (Mutual Funds, Merchant Banks etc.) ensure balance in capital market through reacting according to the interaction between demand and supply. But in recent past they completely did the opposite as 
when there was huge sales pressure in the market instead of buying, they also sold shares in a large scale resulting further decline. Their behavior in that case was not different from individual investors. Hence, they need to act in the way mentioned below:

i) They must show mature behavior to ensure balance in the stock market by buying shares when there is sale pressure and vice-versa.

ii) At the time of huge decline they should not be involved in forced/trigger sale of clients' shares without giving them any chance to adjust their loan.

iii) All sorts of transactions through omnibus accounts should be restrained.

\subsection{Recommendations for Individual Investors}

No matter what is the reason of a crash, individual investors are the ultimate losers. Hence, it is their own duty to take care of their own money and they ought to consider the following things while taking investment decisions.

i) Before investing in a particular script they must analyze the key factors of that company to justify whether the company is fundamentally strong. Such factors include EPS, P/E Ratio, NAV, future growth, industry average etc.

ii) In analyzing financial strength of a company they must consider the audited annual reports instead of quarterly un-audited report as often these information is not accurate or do not reflect the real position of the company.

iii) They must restrict themselves from buying junk shares and taking whimsical investment decision.

iv) Instead of being traders, the retail investors need to think of being investors and they should not buy on the basis of rumor or following advices of the persons who do not possess sufficient knowledge about capital market investment.

v) They ought to participate in different seminars and training programs relating to stock market to enhance their knowledge and skill in making stock market investment decisions.

vi) They must know that both gain and loss are the indispensable parts of stock market. Instead of looking for gain, sometimes they must accept loss with patience so that they may recover the loss in future through higher gain. And above all, they must understand that perseverance and patience is the key to success in investing in capital market.

\section{Conclusion}

As an important part of the economy of the country, well-functioning of the capital market is a must for the industrialization process of a un-industrialized country like Bangladesh but un-stability in the same may negatively affect the total financial system. Therefore, all related corners including Government, Regulatory bodies, Listed Companies, Brokerage houses, institutional investors, and retail investors should act rationally to maintain the stability in the capital market for the greater interest of the country.

\section{References}

Akkas, S. M. A. (2011). Review of Bangladesh Capital Market Instability from National Macroeconomic Management Perspective under the global Policy Regimes of Post-Recession Recovery. Economic Research, 12, 81, May.

Ali, M. A. (2011). The view of general investors towards Bangladesh Bank's strategy performance. The Daily Star, Dated: 21 st April.

Bangladesh Bank. http://www.bangladesh-bank.org

Chittagong Stock Exchange. http://www.cse.com.bd

Chowdhury, A. K. M. (2005). Demutualization: Current Trend of Stock Exchange Reform. Portfolio, 10th Foundation Anniversary of Chittagong Stock Exchange, p.42-44.

Chowdhury, T. A. (2005). An Overview of Bangladesh Stock Markets, Portfolio, 10th Foundation Anniversary of Chittagong Stock Exchange, p.45-50.

Dhaka Stock Exchange. http://www.dsebd.org/

Islam, M. N. (2011). Problems and Prospects of Stock Market in Bangladesh. Economic Research, 12, p.67, May 2011.

Monem, R. (2011). In Search of a Cure for the capital market. The Financial Express, Dated: March 23, 2011. http://www.thefinancialexpress-bd.com/ 
Mufazzal, M. (2012). MoF asks SEC not to intervene in stock market unnecessarily. The Financial Express, Dated: January 15, 2012. http://www.thefinancialexpress-bd.com/more.php?news_id=93996

Newspapers. http://www.onlinenewspapers.com/banglade.htm

Securities and Exchange Commission. http://www.secbd.org/

Worldwide Business \& Financial news site. www.bloomberg.com

Note

Note 1. A-Category: companies which both declare dividend at least 10\% and hold AGM regularly; B-Category: companies which either declare dividend at least 10\% or hold AGM regularly; Z-Category: companies which don't declare dividend at least $10 \%$ and not hold AGM regularly; and N-category: companies which are new that not yet complete one year of listing in the market. 